\title{
The Service Quality Evaluation on Tourist Loyalty in Malaysian Hotels by the Mediating Role of Tourist Satisfaction
}

Yousef Keshavarz

Mass Hareeza Ali

Department of Marketing, Faculty of Economics and Management, Universiti Putra Malaysia (UPM), Serdang, Selangor, Malaysia, 43400 Doi:10.5901/mjss.2015.v6n3s2p680

Email: mass@upm.edu.my

\section{Abstract}

The purpose of this study is to investigate the influence of service quality on tourism loyalty in the hotel industry. Data were collected from international tourists at several top interested places locations in Kuala Lumpur. The study sample included international tourists who stay in four and five star hotels in Kuala Lumpur. Service quality with five dimensions includes reliability, assurance, responsiveness, tangible, and empathy is considered as independent variables. From the result of the study, it was found that service quality affects tourist satisfaction and loyalty directly. The finding of this study is helpful for hotel industry. In fact, the finding of this research informs hotelier to understand about the tourist attitude toward service quality in hotel and its impact on their satisfaction and loyalty.

Keywords: hotel, Malaysia, service quality, satisfaction, loyalty

\section{Introduction}

In Malaysia, the tourist industry has rapid growth in these years and based on the National Development Policy-Vision 2020, national income from inbound tourists, as the fourth industry, is predicted to reach $20.9 \$$ billion and 497200 job opportunities (Ramachandrann, 2010). Moreover, according to UNWTO (2013) the number of domestic tourists in 2011 is 162835000 who spent RM 42346 million or RM 260 per trip. Most of domestic tourists (83.5\%) stay at their friends or relatives houses and 14.2 percent of them stay at hotels, while most of international tourist stay in the hotels, apartments or budget hotels (Department of Statistics, 2012). Therefore, hotel industry in Malaysia is one of the important industries, which help to economic development. There are 1736 (until June 2012) registered hotels apartments and budget hotels in Malaysia. Of these, 929 are qualified hotels which categorized from 1 to 5 stars (Malaysia tourism satellite account MTSA, 2013).

Rapid growth of hotels in Malaysia leads to compete in uncertain business environment. Right planning and practice help them to get best opportunities from the external environment based on internal strengths (Razalli, 2008). Service quality in hotel is considered as important factor to influence customer to be loyal, hence attract more customers. Since 1920s when the first service research had started (Akbaba, 2006), so many researches has carried out about service quality and customer loyalty (Lee et al., 2011; Lin, 2005; Tanford et al., 2012; Wilkins et al., 2007). However, from the literature it is realized that there is a little researches have designed to investigate the relationship between service quality and customer loyalty in hotels especially in Malaysian hotels

Customer loyalty is the most important source of competitive advantages for service companies. It not only leads to competitive advantages, but also makes employees more productive and moral (Lee \& Cunningham, 2001). It is also supported by several researches that increasing customer loyalty affects a company to have an important marketing and economic advantage (Abdul-Rahman \& Kamarulzaman, 2012). For example, Reicbheld and Sasser (1990) stated that 5 percent increasing of customer loyalty contribute to 25 to 85 percent (depending on the service industry) increasing in company profit.

In this study the relationship between service quality and tourist's loyalty in Malaysian hotels was investigated. Moreover, the variable of tourist's satisfaction was considered as mediator variable. The importance of this study is because of the important of tourism industry in Malaysia. Tourism industry play a vital role in Malaysian economic growth and hotels play an important part of this industry. Therefore, this study aims to investigate the variables affect hotels to attract more customers by loyalty programs.

\section{Background}

\subsection{Service quality}

One of the most important factor for determination of customer loyalty is the overall perceived service quality (Chu, Lee, \& Chao, 2012). Service quality affect hotels to attract new customers and lead to customer loyalty, positive word-of-mouth, enhance 
employee satisfaction, commitment and corporation and reduce cost, hence increase business performance (Akbaba, 2006).

One of the well-known models regarding to service quality provided by Parasuraman et al. (1985) is called SERVQUAL. In this model, ten dimensions were considered as quality of service including reliability, responsiveness, competency, access, courtesy, communication, credibility, security, understanding, and knowing the customer. These dimensions were modified during the time. Parasuraman et al. (1988) decreased the dimensions into five including tangible, responsiveness, reliability, assurance, and empathy. Ting (2003) used SERVQUAL technique to provide gap between customer expectation of service quality and service provided in hotel industries and suggested hotel managers to improve the quality to affect their customer's satisfaction.

Grönroos (1990) identified six dimensions of service quality by which, customers can measure the quality of service. These dimensions include professionalism and skills, attitudes and behavior, reliability and trustworthiness, accessibility and flexibility, credibility and recovery, and reputation. Furthermore, Ekinci et al. (2003) used modified SERVQUAL to realize that customers are more interested from intangible service qualities than tangible.

Knutson et al. (1990) used SERVQUAL model in hotel industry and provided new model called LODGSERV. Akbaba (2006) used SERVQUAL scale to measure customer evaluation from the hotel services. Therefore, in this study tried to investigate the most famous dimensions of service quality include tangible, assurance, reliability, responsiveness, and empathy. Moreover, the relationship between service quality with other variables based on literature was provided as below hypotheses:

\subsection{Loyalty}

At the recent years, increasing competition between companies especially service firms forced them to pay attention to potential customers and make all their efforts to maintain current customer (Abdul-Rahman \& Kamarulzaman, 2012, Keshavarz \& Nezakati, 2013). The major concept affect customer to stay with the company is customer loyalty. Loyal customer is defined as a person who interest to rebuy from the service provider even he or she has another provider and recommend it to others by word of mouth (Liu et al., 2012). Loyalty is important for both customers and firms. Loyal customers spend minimum time and effort to search, locate, and evaluate purchase alternative. On the other hand, for companies loyal customer is one of the most important factor to success in market and achieve the goals, because their sensitivity toward the price is decreased and publish positive word of mouth about the service provider (Yang \& Peterson, 2004).

Oliver (1999) provided four stages of loyalty include cognitive, affective, conative, and action. In first path customer is loyal to firm or service provider based on his or her information. Affective is the second stage of loyalty in which customer positive attitude toward provider plays an important role to be loyal. In third path, conative loyalty or behavioral intention, a deeply commitment is happened for buying from the service provider. Finally, in last step intention is converted into action. In fact, in this stage customer try to overcome obstacles to purchase, therefore measuring loyalty at this phase is difficult.

Theory of Reasoned Action (TRA) developed by Fishbein and Aizen (1975) is the fundamental and influential theory, which can be used in this study. Based on the theory of reasoned action, behavioral intention is a function of two factors, attitude towards behavior and subjective norm. Attitude denotes to the customer behavior rather that to his/her performance in general. Subjective norm is a function of a set of beliefs termed as normative beliefs. Normative beliefs are concerned with the "likelihood that important referent individuals or groups would approve or disapprove of performing the behavior" (Meskaran et al., 2013).

The importance of tourist loyalty is provided by many researches and it has believed that affect firms to have competitive advantage ( see for example Abdul-Rahman \& Kamarulzaman, 2012; Anderson, \& Sullivan, 1993; Weber, 2001; Tsaur et al. 2002; Rauyruen, \& Miller, 2007; Yoon \& Uysal, 2005; Tanford et al. 2012). Loyalty is considered as two aspects. Although some researchers had recognized it as behavioral aspects (Cyr et al., 2007; Oliver, 1999), concept or attitudinal aspect of loyalty is also considered by other researchers (Bloemer et al., 1999; Carpenter \& Fairhurst, 2005). There are several researches had supported the idea that satisfaction lead to loyalty (Heitmann et al., 2007; Zeithaml et al., 1996), however in some researches had reported that there are low relationship between satisfaction and loyalty (Oliver,1999; Olsen, 2007). Therefore, according to Olsen (2007), the link between customer satisfaction and loyalty is different between industries, because many factors affect customers to be satisfied and they vary in different industries.

According to Johnson et al. (2001) trust, satisfaction and commitment, staff behavior before and during the event, and price are the most important factors contribute to loyalty.

\subsection{Satisfaction}

Amin et al. (2013) argued that the main challenge for hotel industry is customer satisfaction and service quality. Therefore, hotels need to enhance service quality to affect their customers to be satisfied and return to hotel in future or suggest to others.

Kim et al. (2007) found that recommendation intention, re-subscription intention, and new service subscription intention were indicators of loyalty. They stated that customer satisfaction in a period of time had a cumulative effect on level of customer loyalty. Lin (2005) believed satisfied customers are more likely to revisit hotel, Increasing only $2 \%$ customers helps 
hotel to enhance profitability by $10 \%$, therefore keep exist customers can help hotels to decrease their cost 6 to 15 times and most companies especially hotels have realized that by satisfied customers they can reach this goal.

According to Oliver (1980) customer satisfaction is consequence of customer expectation and customer perception of service quality. Fornell et al. (1996) also believed that customer satisfaction is consequence of customer expectation, perception and value perception. Oliver (1999) argued that satisfaction and loyalty are linked inseparably, although other factors also affect loyalty.

The Confirmation (Expectancy)-disconfirmation theory defines the satisfaction as a "post-purchase evaluative judgment concerning a specific buying decision." Based on this theory, the customers evaluate their satisfaction levels by comparing their expectations about the service or product with the actual experience (Skogland \& Siguaw, 2004).

This study investigates the structural relationships among three interrelated constructs: service quality with five dimensions, tourist satisfaction, and tourist loyalty. Based on the literature review, the following hypotheses were formulated:

$\mathrm{H} 1$ : service quality influences tourist satisfaction significantly.

$\mathrm{H} 2$ : service quality is significantly influence tourist loyalty.

H3: tourists` satisfaction has a significant effect on tourists` loyalty.

H4: tourists` satisfaction has mediating affect in the relationship between service quality and tourist loyalty.

\section{Methodology}

This research employed self-administrative questionnaire for Malaysian hotel guests. The number of valid questionnaires was 417, of 500 distributed once. The international tourists who stay in four and five star hotels in Kuala Lumpur were the population target. There are 45 four and five star hotels in Kuala Lumpur (MTSA, 2013). The data was collected by the questionnaire through the top visiting places in Kuala Lumpur including Petronas twin towers, BBKLCC, Aquaria, KL tower, Central market, and Putrajaya.

Service quality was measured based on Parasuraman et al. (1988). In fact, five dimensions of service quality were considered in this research includes tangible, reliability, assurance, responsiveness, empathy. Furthermore, based on the literature tourist's satisfaction is provided as mediator variable by four questions and loyalty was provided as independent variable by six questions. Therefore, the research model is provided below:

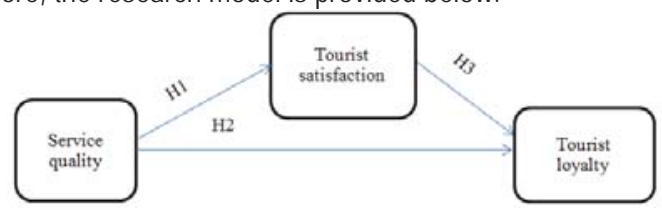

Figure 1: Research model

In this research, SEM is used to test various models concerning the interrelationships among a set of variables. This technique has been well known in marketing researches especially appropriate for theory testing. SEM provides a way to test the specified set of relationships among observed and latent variables as a whole, and allow theory testing even when experiments are not possible(Savalei \& Bentler, 2010). Therefore the SEM was provided to support the theory of Confirmation (Expectancy)-disconfirmation and the theory of Reasoned Action (TRA).

\section{Finding}

To analyses the data, AMOS 21.0 was performed to test the hypothesized model. The result of the analysis was provided below.

As it is provided in Table 1, of the 417 respondents who provided gender information, 291 (69.8\%) were male, whereas 126 (30.2\%) were female respondents. The largest age group of the respondents was 25 to 34 years (34.3\%), followed by 35 to 44 years (25.4\%), 45 to 54 years (17.3\%), 18 to 24 years $(15.6 \%), 55$ to 64 years $0(6.5 \%)$, and 65 years and more (1\%). Around $50.8 \%$ of respondents were from Asian countries, followed by Middle East (20.6\%) and Europe countries (18.2\%), and respondent from other countries were at the last (10.3\%).

Table 1: Demographic Characteristics of the Respondents

\begin{tabular}{lcc}
\hline Respondents & Frequency & Percent (\%) \\
\hline Sex & & \\
Male & 291 & 69.8 \\
Female & 126 & 30.2 \\
Age & 65 & 15.6 \\
$18-24$ & 143 & 34.3 \\
$25-34$ & 0 & \\
& 682 &
\end{tabular}




\begin{tabular}{lcc}
\hline $\mathbf{3 5 - 4 4}$ & 106 & 25.4 \\
$\mathbf{4 5 - 5 4}$ & 72 & 17.3 \\
$\mathbf{5 5 - 6 4}$ & 27 & 6.5 \\
$\mathbf{6 5}$ and more & 4 & 1 \\
Nationality & & \\
Asian countries & 212 & 50.8 \\
Middle East & 86 & 20.6 \\
European countries & 76 & 18.2 \\
Others & 43 & 10.3 \\
\hline
\end{tabular}

Mean scores and correlation coefficients were first computed to examine the distribution and relationship of the data, respectively. The correlation matrix is shown in Table 2 . The correlation coefficients ranged from 0.40 to 0.63 , with all correlation coefficients significant at $p<0.001$. All constructs were found to have a significant correlation with tourist loyalty. The correlation matrix did not indicate multicollinearity, since no correlation coefficient was greater than 0.80 (Billings \& Wroten, 1978). In addition, reliability analysis entailed a good intercorrelation among items within each multiscale construct: service quality ( $\alpha=0.97)$, tourist satisfaction $(\alpha=0.92)$, and tourist loyalty $(\alpha=0.91)$.

Table 2: Mean, Standard Deviation and Correlation Matrix of Constructs

\begin{tabular}{lcccccc}
\hline Variable & Mean & S.D. & A & 1 & 2 & 3 \\
\hline (1)Service quality & 3.672 & 23.5 & .971 & 1 & & \\
(2)Tourist satisfaction & 3.540 & 3.7 & .920 & $.40^{\text {**+* }}$ & 1 & \\
(3)Tourist loyalty & 3.385 & 5.1 & .915 & $.50^{\text {**+* }}$ & $.63^{\text {*+*t }}$ & 1 \\
\hline
\end{tabular}

Since the loading value of some scales (Rel2, Emp4, Tang1, Loy4, and Loy5) were less than .60, therefore were deleted. The reviewed model for the CFA showed reasonable fit between the observed data. Convergent validity in the revised model was achieved. As shown in Table 3 the loadings for indicators of all variables were more than .60, which is mentioned by Hair et al. (2006). Moreover, AVE values ranged from 0.577 to 0.752 , which all exceeded the recommended level of 0.5 (Hair et al., 2006).

Therefore, the results approve the discriminant validity of service quality construct in the measurement model. Having satisfied the measurement requirements, hypothesis-testing using structural equation model was subsequently tested.

Table 3: Confirmatory Factor Analysis Results

\begin{tabular}{|c|c|c|c|}
\hline Contract & Items & Loading & AVE \\
\hline \multirow[t]{5}{*}{ Assurance } & -- & -- & \multirow{5}{*}{.647} \\
\hline & Asu1 & .83 & \\
\hline & Asu2 & .85 & \\
\hline & Asu3 & .80 & \\
\hline & Asu4 & .73 & \\
\hline \multirow[t]{4}{*}{ Reliability } & -- & -- & \multirow{4}{*}{.677} \\
\hline & Rel1 & .83 & \\
\hline & Rel3 & .80 & \\
\hline & Rel4 & .83 & \\
\hline \multirow[t]{4}{*}{ Responsiveness } & -- & -- & \multirow{4}{*}{.66} \\
\hline & Res1 & .83 & \\
\hline & Res2 & .82 & \\
\hline & Res3 & .78 & \\
\hline \multirow[t]{7}{*}{ Empathy } & -- & -- & \multirow{7}{*}{.577} \\
\hline & Emp1 & .85 & \\
\hline & Emp2 & .75 & \\
\hline & Emp3 & .81 & \\
\hline & Emp5 & .76 & \\
\hline & Emp6 & .75 & \\
\hline & Emp7 & 61 & \\
\hline \multirow[t]{6}{*}{ Tangible } & -- & -- & \multirow{6}{*}{.642} \\
\hline & Tang2 & .70 & \\
\hline & Tang3 & .85 & \\
\hline & Tang4 & .81 & \\
\hline & Tang5 & .80 & \\
\hline & Tang6 & .83 & \\
\hline \multirow[t]{5}{*}{ Tourist satisfaction } & -- & -- & \multirow{5}{*}{.752} \\
\hline & Sat1 & .88 & \\
\hline & Sat2 & .93 & \\
\hline & Sat3 & .90 & \\
\hline & Sat4 & .75 & \\
\hline
\end{tabular}




\begin{tabular}{lccc}
\hline Tourist loyalty & -- & - & \\
& Loy1 & .89 & \\
Loy2 & .94 & .685 \\
& Loy3 & .83 & \\
Loy6 & .62 & \\
\hline
\end{tabular}

The results of SEM are showed in Table 5 and Figure 2. As shown in goodness of-fit indices, including CFI and GFI, are 0.955 for the models, and were well above the recommended level of 0.9 (Byrne, 2001) and RMSEA $=0.053<0.08$. Moreover, Chi square/ $\mathrm{df}=2.178<5.0$ (Awang, 2012). These indicated that hypothesized model is relatively good approximations of the underlying population and is considered satisfactory.

Table 4 presents the path coefficients and each construct's critical ratio (C.R.). The results show that service quality was the significant factor affecting the tourist satisfaction and tourist loyalty at $P$ value of 0.001 (Estimate .58 and .29 respectively). Therefore, $\mathrm{H} 1$ and $\mathrm{H} 2$ were supported. The tourist loyalty was positively influenced by the tourist satisfaction at $p<0.001$ and standardized regression weight 0.58 . Therefor the results supported hypothesis $\mathrm{H} 3$.

As revealed in Figure 2, the hypothesized model explained $34 \%$ of the variance in tourist satisfaction, $62 \%$ in tourist loyalty.

Table 4: Structural Equation Modeling Results

\begin{tabular}{|c|c|c|c|}
\hline Hypothesis & Estimate & C.R. & Results \\
\hline $\mathrm{H} 1$ & .58 & $11.590^{\text {tht }}$ & Supported \\
\hline H2 & .29 & $6.567^{\star \star *}$ & Supported \\
\hline H3 & .58 & $11.866^{+1+x}$ & Supported \\
\hline \multicolumn{2}{|c|}{ Chi-Square/ Degree of Freedom } & 2.166 & \\
\hline \multicolumn{2}{|c|}{$\mathrm{p}$ value } & 0.000 & \\
\hline \multicolumn{2}{|c|}{ RMR } & .068 & \\
\hline \multicolumn{2}{|c|}{ GFI } & .862 & \\
\hline \multicolumn{2}{|c|}{ AGFI } & .840 & \\
\hline \multicolumn{2}{|c|}{ IFI } & .955 & \\
\hline \multicolumn{2}{|c|}{ CFI } & .955 & \\
\hline \multicolumn{2}{|c|}{ RMSEA } & .053 & \\
\hline
\end{tabular}

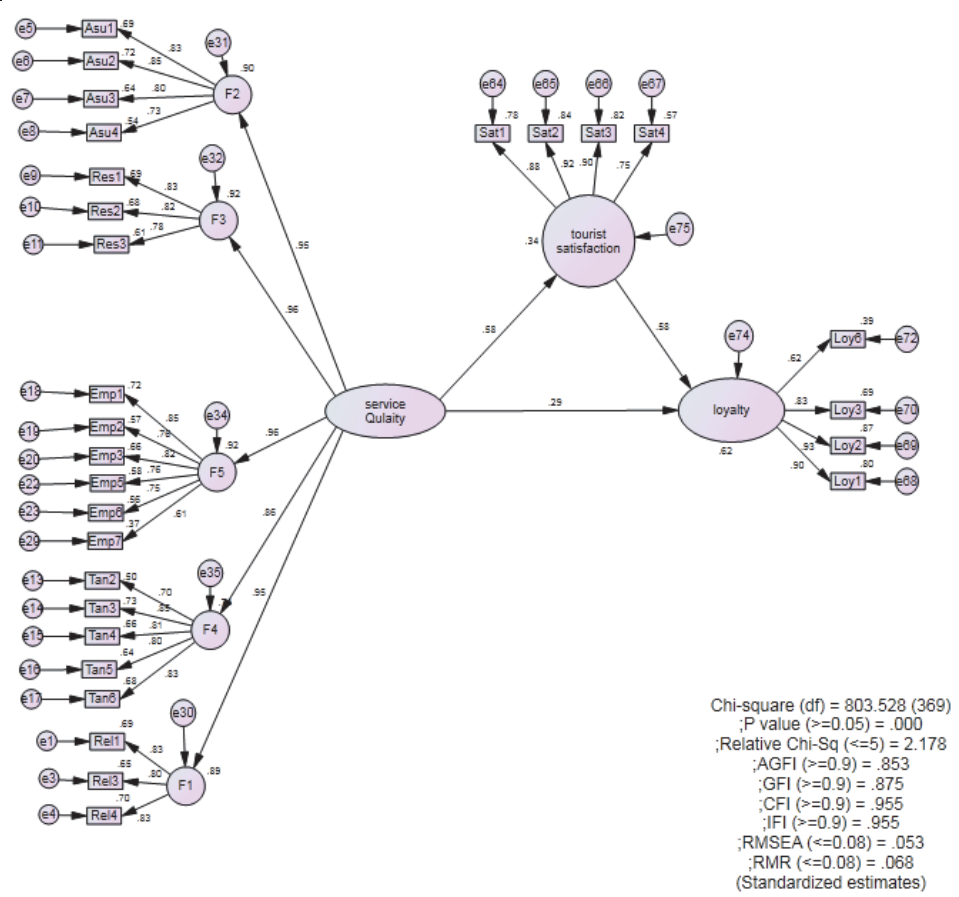

Figure 2: Relationship of the Different Constructs in the Model

Moreover, the normal theory method of testing mediation effects explained by Baron and Kenny (1986) was employed to test the mediation effect of tourist satisfaction in the relationship between the service quality and tourist loyalty. In this 
method, in the first step the initial model with only a direct effect between the independent variables and the dependent variable was estimated. In the second step, a second model was estimated in which the mediating variable would be added to the model and the two additional paths between the independent to mediation variables and mediation to dependent variable were calculated (Hair et al., 2007).

The results, as demonstrated in Table 5, show that in the direct model the relationship between service quality and tourist loyalty was significant $(\beta=0.417)$. Also, the results based on the mediation model show a significant relationship between service quality and tourist satisfaction $(\beta=0.332)$, and tourist satisfaction with tourist loyalty $(\beta=0.476)$. Moreover, the size of standard regression weight for the direct relationship between service quality and tourist loyalty reduced when tourist satisfaction was included as an additional prediction in the mediation model, and not significant ( $\beta$ =. 001), thus the full mediation of tourist satisfaction on the relationship between service quality and tourist loyalty was supported. Therefore the fourth hypotheses was supported. The result is consistent with previous findings that a tourist satisfaction plays as a mediator in the relationship between process quality and tourist loyalty (Chitty et al., 2007; Ekinci et al., 2003; Keshavarz \& Ali, 2015 ).

Table 5: Regression Weight in the Full Mediation, Indirect, and Direct Model

\begin{tabular}{cccccc}
\hline DV & & IV & Mediation Model & Indirect Model & Direct Model \\
\hline Tourist satisfaction & $\leftarrow$ & Service quality & $.332^{* * *}$ & $.314^{* * *}$ & $.417^{* * *}$ \\
Tourist loyalty & $\leftarrow$ & Service quality & .001 & $.496^{* * *}$ \\
Tourist loyalty & $\leftarrow$ & Tourist satisfaction & $.476^{* * *}$ & .40
\end{tabular}

\section{Conclusion and Discussion}

The importance of customer satisfaction and making them loyal customers is widely known by hotelier (Amin et al., 2013). The current study provide a model that aimed to give a better understanding of the role of tourist satisfaction in mediating the relationship between the service quality and tourist loyalty in the Malaysian hotel setting. Relationships of the four constructs in the model are presented in Figure 2. The results of the study are as follows:

- Tangible, responsiveness, assurance, empathy, and reliability are the five dimensions of service quality.

- Service quality influences both tourist satisfaction and tourist loyalty.

- Tourist satisfaction affects tourist loyalty

- Tourist satisfaction has mediating affect in the relationship between service quality and tourist loyalty.

This study concurs with previous outlooks on the roles of service quality related constructs (Oliver, 1980; Grönroos, 1990; Kim et al., 2007, Chu et al., 2012, Keshavarz \& Ali, 2015). It highlights the importance of tourist satisfaction in mediating the relationship between service quality and tourist loyalty. By present vision into the mediator influence of tourist satisfaction, this study provided a framework for evaluating the interactions between service quality (including five dimension, tangible, responsiveness, assurance, empathy, and reliability) and tourist loyalty in hotel industry. Moreover the result of this study was supported by the theory of Reasoned Action (TRA) and the Confirmation (Expectancy)disconfirmation theory.

In a highly competitive environment, hoteliers need to pay attention to tourist loyalty as it is determined by the service quality. In particular, hoteliers should focus on the responsiveness and empathy at the first priority as it presents the essence for service quality. This confirms previous studies about the importance of dimensions of service quality to customers. In conclusion, keeping and enhancing loyalty is essential to the relationship between guest and hoteliers. Although service quality is a sensible and complex process, the results of the study clarify that it is worth making such efforts when tourist satisfaction and loyalty result from improved service quality. To scholars, tourist satisfaction should be considered into models designed to understand the determinants of tourist loyalty. To hoteliers, tourist loyalty needs to be considered in conjunction with tourist satisfaction when designing and delivering the services, while tourist satisfaction needs to be enhanced and raised to motivate high levels of tourist loyalty.

A limitation of this study is that other variables such as outcome quality are not considered. Therefore, in the further research it is suggested to identify the tourist loyalty based on both process and outcome quality. Future research may also be directed at further investigating the impacts of service quality and customer loyalty on organizational performance measures, such as profitability.

\section{Reference}

Abdul-Rahman, M., \& Kamarulzaman, Y. (2012). The Influence of Relationship Quality and Switching Costs on Customer Loyalty in the Malaysian Hotel Industry. Procedia-Social and Behavioral Sciences, 62(24), 1023-1027.

Akbaba, A. (2006). Measuring service quality in the hotel industry: A study in a business hotel in Turkey. International Journal of Hospitality Management, $25(2), 170-192$. 
Amin, M., Yahya, Z., Ismayatim, W. F. A., Nasharuddin, S. Z., \& Kassim, E. (2013). Service Quality Dimension and Customer Satisfaction: An Empirical Study in the Malaysian Hotel Industry. Services Marketing Quarterly, 34(2), 115-125.

Anderson, E. W., \& Sullivan, M. W. (1993). The antecedents and consequences of customer satisfaction for firms. Marketing science, 12(2), 125-143.

Awang, Z. (2012). A handbook on SEM: Structural equation modelling, Kuala Lumpur, Malaysia: Center of Graduate Studies.

Billings, R. S., \& Wroten, S. P. (1978). Use of path analysis in industrial/ organizational psychology: criticism and suggestions. Journal of Applied Psychology, 63(6), 677688.

Bloemer, J., De Ruyter, K., \& Wetzels, M. (1999). Linking perceived senvice quality and service loyalty: a multi-dimensional perspective. European Journal of Marketing, 33(11/12), 1082-1106.

Byrne, B. M. (2001). Structural equation modeling with AMOS: basic concepts, applications, and programming. Mahwah, NJ: Lawrence Erlbaum Associates.

Chitty, Bill, Ward, Steven, \& Chua, Christina. (2007). An application of the ECSI model as a predictor of satisfaction and loyalty for backpacker hostels. Marketing Intelligence \& Planning, 25(6), 563-580.

Chu, P.-Y., Lee, G.-Y., \& Chao, Y. (2012). Service quality, customer satisfaction, customer trust, and loyalty in an e-banking context. Social Behavior and Personality: an international journal, 40(8), 1271-1283.

Cyr, D., Hassanein, K., Head, M., \& Ivanov, A. (2007). The role of social presence in establishing loyalty in e-Service environments. Interacting with Computers, 19(1), 4356.

Department of Statistics, M. (2012). Domestic Tourism Survey http://mww.statistics.gov.my/portal/images//tories/files/LatestReleases/findings/ summary_findings_dts2011.pdf.

Ekinci, Y., Prokopaki, P., \& Cobanoglu, C. (2003). Service quality in Cretan accommodations: marketing strategies for the UK holiday market. International Journal of Hospitality Management, 22(1), 47-66.

Fishbein, Martin, \& Ajzen, Icek. (1975). Belief, attitude, intention and behavior: An introduction to theory and research. Victoria: ARRB Group.

Fornell, C., Johnson, M. D., Anderson, E. W., Cha, J., \& Bryant, B. E. (1996). The American customer satisfaction index: nature, purpose, and findings. Journal of Marketing, 60(4), 7-18.

Grönroos, C. (1990). Senvice management and marketing: managing the moments of truth in service competition. Lexington: MA.

Hair, J. F., Black, W. C., Babin, B. J., Anderson, R. E., \& Tatham, R. L. (2006). Multivariate data analysis, 6th ed. NJ: Pearson.

Heitmann, M., Lehmann, D. R., \& Herrmann, A. (2007). Choice goal attainment and decision and consumption satisfaction. Journal of marketing research, 44(2), 234250.

Johnson, M. D., Gustafsson, A., Andreassen, T. W., Lervik, L., \& Cha, J. (2001). The evolution and future of national customer satisfaction index models. Journal of Economic Psychology, 22(2), 217-245.

Keshavarz, Y., Ali, M. H.(2015). The investigation of the hotels service quality effects on tourist Loyalty, international journal of AYER, 2, 327-342

Keshavarz, Y, Nezakati H. (2013). The Effects of Malaysian Hotels Services on Customer Loyalty, 4 (10), 287-292.

Kim, K.-J., Park, J.-C., Park, Y.-J., Kim, C.-G., \& Kim, T.-H. (2007). The impact of network service performance on customer satisfaction and loyalty: High-speed internet service case in Korea. Expert Systems with Applications, 32(3), 822-831.

Knutson, B., Stevens, P., Wullaert, C., Patton, M., \& Yokoyama, F. (1990). LODGSERV: A service quality index for the lodging industry. Journal of Hospitality \& Tourism Research, 14(2), 277-284.

Lee, M., \& Cunningham, L. F. (2001). A cost/benefit approach to understanding service loyalty. Journal of services Marketing, 15(2), 113-130.

Lee, S., Jeon, S., \& Kim, D. (2011). The impact of tour quality and tourist satisfaction on tourist loyalty: The case of Chinese tourists in Korea. Tourism Management, 32(5), 1115-1124.

Lin, C. H. (2005). relationship between guest perception of service quality and customer loyalty in the hotel industry in south Florida. Lynn university. (unpublished dissertation)

Liu, S., Law, R., Rong, J., Li, G., \& Hall, J. (2012). Analyzing changes in hotel customers' expectations by trip mode. International Joumal of Hospitality Management, 34, 359-371.

Meskaran, Fatemeh, Ismail, Zuraini, \& Shanmugam, Bharani. (2013). Online purchase intention: Effects of trust and security perception. Australian Journal of Basic and Applied Sciences, 7(6), 307-315.

"MTSA". (2013). Malaysia Tourism Satelite Account. Kula Lumpur http://umw.statistics.gov.my/portal/download_Services/files/DTS/DTS_2012.pdf.

Oliver, R. L. (1980). A cognitive model of the antecedents and consequences of satisfaction decisions. Journal of marketing research, 17(4), 460-469.

Oliver, R. L. (1999). Whence consumer loyalty. Journal of Marketing, 63(4), 33-44.

Olsen, S. O. (2007). Repurchase loyalty: the role of involvement and satisfaction. Psychology \& Marketing, 24(4), 315-341.

Parasuraman, Zeithaml, V. A., \& Berry, L. L. (1985). A concepyual model of service quality and its implications for future research Journal of Marketing, 49(4), 41-50.

Parasuraman, Zeithaml, V. A., \& Berry, L. L. (1988). SERVQUAL- A Multiple-Item Scale for Measuring Consumer Perceptions of Service Quality. Journal of Retailing, 64(1), $12-40$.

Ramachandrann, G. (2010). Experts of the government transformation programme(GTP) \& economic transportation programme(ETP): key thrusts to power the nation towards 2020.

Rauyruen, P., \& Miller, K. E. (2007). Relationship quality as a predictor of B2B customer loyalty. Journal of Business Research, 60(1), 21-31.

Razalli, M. R. (2008). Service Delivery System Practices in Malaysian Hotel Operations: An Exploratory Study. Malaysian Management Journal, 12(1\&2), 103-115.

Reicbheld, F. P., \& Sasser, W. E. (1990). 7ero Defeciions: Quolify Comes to Services. Harvard business review.

Savalei, Victoria, \& Bentler, Peter M. (2010). Structural equation modeling Corsini Encyclopedia of Psychology. Los Angeles: University of California,

Skogland, I., \& Siguaw, J.A. (2004). Are your satisfied customers loyal? Comell Hotel and Restaurant Administration Quarterly, 45(3), $221-234$.

Tanford, S., Raab, C., \& Kim, Y.-S. (2012). Determinants of customer loyalty and purchasing behavior for full-senvice and limited-service hotels. International Journal of Hospitality Management, 31(2), 319-328.

Ting, K. H. (2003). A study of factors that influence the hotel service quality. (master ), Chaoyang University of Technology,, Taichung,Taiwan.

Tsaur, S.-H., Chiu, Y.-C., \& Huang, C.-H. (2002). Determinants of guest loyalty to international tourist hotels-a neural network approach. Tourism Management, 23(4), 397-405.

UNWTO. (2013). Domestic Tourism in Asia and the Pacific. Madrid.: World Tourism Organization.

Weber, K. (2001). Association meeting planners' loyalty to hotel chains. International Journal of Hospitality Management, 20(3), 259-275.

Wilkins, H., Merrilees, B., \& Herington, C. (2007). Towards an understanding of total service quality in hotels. International Journal of Hospitality Management, 26(4), 840853.

Yang, Z., \& Peterson, R. T. (2004). Customer perceived value, satisfaction, and loyalty: The role of switching costs. Psychology \& Marketing, 21(10), 799-822.

Yoon, Y., \& Uysal, M. (2005). An examination of the effects of motivation and satisfaction on destination loyalty: a structural model. Tourism Management, $26(1), 45-56$.

Zeithaml, V. A., Berry, L. L., \& Parasuraman, A. (1996). The behavioral consequences of service quality. Journal of Marketing, 60(2), 31-46. 